SEHATI

Jurnal Kesehatan
Vol 1, No 2, Agustus 2021, p. 73-82

e-ISSN : 2775-6963 | p-ISSN : 2775-695 DOI:

https://doi.org/10.52364/sehati.v1i2.8

RESEARCH ARTICLE

OPEN ACCESS

\title{
Pengaruh sanitasi lingkungan terhadap kejadian penyakit kulit pada Santriwati di Pondok Pesantren Anshor Al-Sunah Kabupaten Kampar
}

\author{
Ramayanda Gusni ${ }^{1}$, Ridwan Manda Putra ${ }^{2}$, Bayhakki $^{3}$ \\ ${ }^{1,2}$ Pascasarjana Ilmu Lingkungan Universitas Riau \\ ${ }^{3}$ Fakultas Keperawatan Universitas Riau \\ *Correspondent Email : ramayandagusni77@gmail.com
}

Diterima: 12 Agustus 2021 | Disetujui: 30 Agustus 2021 | Diterbitkan: 31 Agustus 2021

\begin{abstract}
Skin disease can also be caused by poor personal hygiene behavior factors. The Anshor AlSunah Islamic boarding school in Kampar Regency is one of the Islamic boarding schools in Kampar Regency, and skin disease is a common health problem and is a major problem in the Anshor Al-Sunah Islamic boarding school in Kampar Regency. The incidence of skin disease in students in 2017 was recorded at 67 cases recorded at the UKS boarding school Anshor Al-Sunah, Kampar Regency, while in 2018 it increased to 86 cases. The research objective was to determine the effect of environmental sanitation on the incidence of skin disease among female students at the Anshor Al-Sunah Islamic Boarding School, Kampar Regency. This type of observational analytic quantitative research using a survey analysis research design approach. Survey analysis. The research was conducted at the Anshor Al-Sunah Islamic boarding school, Kampar Regency, Riau Province and from March to June 2020. Data collection tools used questionnaire sheets and observation sheets. The population was all students in the Anshor Al-Sunah Islamic boarding school, with a sample of 64 people, using proportional random sampling technique. Univariate, bivariate and multivariate analysis. The results of this study were ecological factors, personal hygiene factors that influenced the incidence of skin disease among students. It is hoped that pesantren managers will improve facilities and infrastructure in accordance with health standards to prevent skin disease transmission.
\end{abstract}

Keywords: ecology; environmental sanitation; personal hygiene; incidence of skin diseases

Kesehatan kulit perlu diperhatikan karena kulit merupakan bagian yang paling vital serta merupakan cermin kesehatan dan kehidupan. Kulit adalah jaringan, yang selama ini kurang diperhatikan oleh sebagian besar orang sampai terjadi masalah seperti penyakit kulit. Kulit pada manusia mempunyai peranan yang sangat penting, selain fungsi utama yang menjamin kelangsungan hidup juga mempunyai arti lain yaitu ras, dan sarana komunikasi nonverbal antar individu satu dengan yang lain.

Penyakit kulit adalah kelainan kulit akibat adanya jamur, bakteri, parasit virus maupun infeksi yang dapat menyerang siapa saja disegala umur. Penyakit kulit merupakan penyakit yang sering dijumpai pada masyarakat. Penyakit kulit dapat menyerang seseorang apabila seseorang tersebut memiliki tingkat kekebalan tubuh yang kurang baik. Lingkungan yang sehat dan bersih juga akan membawa efek yang baik bagi kulit. Demikian pula sebaliknya, lingkungan yang kotor akan menjadi sumber munculnya berbagai macam penyakit antara lain penyakit kulit (Harahap, 2010). Penyakit kulit itu di kelompokkan menurut jenis penyakit dan tingkat keganasannya karena ada jenis penyakit kulit yang tidak berbahaya dan ada juga jenis penyakit kulit yang sangat berbahaya hingga dapat menimbulkan kematian. Adapun penyakit kulit dapat di bedakan menurut tingkat pengobatannya ada 2 yaitu penyakit kulit yang dapat di sembuhkan dan penyakit kulit yang sulit untuk di sembuhkan. Oleh karena itu, dalam mengetahui jenis penyakit kulit bagi penderita adalah sesuatu hal yang sangat penting karena akan memudahkan penderita dalam rangka untuk proses pengobatan dan penyembuhan (Aludin, 2018).

Menurut WHO, prevalensi dari semua bentuk penyakit kulit di dunia Tahun 2017 adalah 4,66\%, termasuk penyakit kulit atopik 0,69 eczemanumular $0,17 \%$, dan dermatitis $2,32 \%$ yang menyerang $2 \%$ hingga 5\% dari penduduk. Sedangkan di Indonesia berdasarkan Survei Demografi Kesehatan Indonesia pada Tahun 2016 prevalensinya mencapai 2,93\%-27,5\% (Aludin, 2018).

Hasil Riset Kesehatan Dasar Provinsi Riau Tahun 2017 menunjukkan angka prevalensi penyakit penyakit kulit berada pada urutan tertinggi dari 8 penyakit kategori lainnya, Kota Pekanbaru prevalensinya mencapai 27,50\% (Profil Kesehatan Provinsi Riau, 2017). Laporan Tahunan Dinas Kesehatan Kabupaten Kampar Tahun 2018 menunjukkan dari sepuluh penyakit terbanyak yang berkunjung di puskesmas, penyakit kulit infeksi menduduki peringkat ketiga, setelah ISPA diurutan pertama dan gastritis diurutan kedua. Kejadian penyakit kulit pada Tahun 2018 didapatkan sebanyak 926 kasus. 


\section{SEHATI}

Jurnal Kesehatan
Vol 1, No 2, Agustus 2021, p. 73-82 e-ISSN : 2775-6963 | p-ISSN : 2775-695 DOI: https://doi.org/10.52364/sehati.v1i2.8

Ada banyak faktor yang mempengaruhi kejadian Penyakit kulit, salah satunya adalah ekologi. Ekologi yang buruk seperti akses air yang sulit, ketersediaan kamar mandi dan sarana pembuangan limbah/sampah yang tidak memenuhi syarat, kondisi ruangan yang kotor, minimnya fasilitas kesehatan dan kepadatan hunian yang tidak sesuai dengan standar. Penyakit kulit identik dengan penyakit anak pondok pesantren karena kondisi kebersihan diri yang kurang terjaga seperti kebersihan kulit, kuku, pakaian, handuk dan tempat tidur (Aludin, 2018).

Menurut penelitian Sa'adatin et al (2015) yang dilakukan di pesantren Raudah Boyolali menunjukkan personal hygiene berpengaruh dengan kejadian penyakit kulit. Hasil analisis diperoleh $\mathrm{OR}=$ 2,934 yang artinya, santriwati dengan personal hygiene buruk mempunyai 2,934 kali berisiko menderita penyakit kulit dari pada santriwati dengan personal hygiene baik. Menurut penelitian Indriana (2012) di Pondok Pesantren Mualamin terdapat hubungan yang bermakna antara personal hygiene santriwati meliputi kuku, kulit rambut dan pakaian dengan kejadian penyakit kulit, dengan masing-masing variabel didapatkan nilai $p<0,05$. Menurut penelitian Surtina (2013) terdapat hubungan antara status ekonomi dengan kejadian penyakit kulit pada santriwati di Pesantren Darelhikmah.

Pondok pesantren Anshor Al-Sunah Kabupaten Kampar, merupakan salah satu pondok pesantren yang ada di Kabupaten Kampar, dan penyakit penyakit kulit termasuk masalah kesehatan yang sering terjadi dan menjadi masalah utama di pondok pesantren Anshor Al-Sunah Kabupaten Kampar. Angka kejadian penyakit kulit pada santriwati pada Tahun 2017 tercatat 67 kasus yang tercatat di UKS pondok pesantren Anshor Al-Sunah Kabupaten Kampar, sedangkan pada Tahun 2018 meningkat menjadi 86 kasus.

Berdasarkan hasil survei awal yang dilakukan oleh peneliti terhadap 10 orang santriwati yang tinggal di Pondok pesantren Anshor Al-Sunah Kabupaten Kampar, diperoleh data sebanyak 7 orang diantaranya menyatakan kurang membersihkan tubuh dan pakaian sehingga tingkat hal ini berdampak pada personal hygiene santriwati, hal ini disebabkan air yang kurang. Selain itu dari 7 orang tersebut 6 diantaranya mengaku pernah mengalami penyakit kulit yang menunjukkan gejala penyakit kulit seperti gatal-gatal dan ruam, dimana gatal-gatal sering dialami santriwati pada malam hari, rasa gatal yang sangat berlebihan menyebabkan terjadinya iritasi pada kulit, selain itu tempat yang digunakan untuk beristirahat kurang memenuhi kebersihan, sprei dan tempat tidur yang sudah lama tidak dicuci dan dijemur menyebabkan bakteri tersebut mudah untuk berkembangbiak, bakteri tersebut sangat senang hidup pada daerah yang lebab, kotor dan serta sanitasinya buruk. Sedangkan 1 orang lainnya tidak mengalami penyakit kulit karena personal hygienenya baik.

\section{METODE PENELITIAN}

Jenis penelitian kuantitatif analitik observasional dengan menggunakan pendekatan desain penelitian Analisis survey. Analisis survey. Penelitian dilakukan di pondok pesantren Anshor Al-Sunah Kabupaten Kampar Provinsi Riau dan pada bulan Maret hingga Juni 2020. Alat pengumpulan data dengan menggunakan lembar kuesioner dan lembar observasi. Populasi adalah seluruh santriwati yang ada di pondok pesantren Anshor Al-Sunah, dengan sampel 64 orang, dengan teknik proposional random sampling. Analisa dengan univariat, bivariate dan multivariate.

\section{HASIL DAN PEMBAHASAN}

\section{Hasil Observasi dan Hasil Penelitian}

Berdasarkan hasil observasi variabel ekologi yaitu ketersediaan dan kebersihan air, ketersediaan kamar mandi/WC, sarana pembuangan limbah/sampah, kondisi kamar, dan kepadatan hunian kamar santriwati yang dilakukan Pondok pesantren Anshor Al-Sunah didapatkan hasil sebagai berikut:

Tabel 1. Ekologi Pondok pesantren Anshor Al-Sunah

\begin{tabular}{lll}
\hline & $\begin{array}{l}\text { Melihat kondisi lingkungan } \\
\text { pesantren }\end{array}$ & Sesuai dengan syarat kesehatan ligkungan \\
\hline \multirow{6}{*}{ Ekologi } & Kebersihan air & Memenuhi syarat \\
& Sarana kamar mandi & Tidak memenuhi syarat \\
& sarana pembuangan & Tidak Memenuhi syarat \\
& limbah/sampah & Tidak memenuhi syarat \\
& Kondisi kamar & Tidak memenuhi syarat \\
\hline
\end{tabular}


Berdasarkan hasil observasi variabel ekologi yaitu kondisi dan kebersihan air, ketersediaan kamar mandi/WC, sarana pembuangan limbah/sampah, kondisi kamar, dan kepadatan hunian kamar santriwati yang dilakukan Pondok pesantren Anshor Al-Sunah didapatkan hasil :

Untuk variabel kondisi dan kebersihan air, didapatkan hasil obeservasi dimana kebersihan air terlihat warna air jernih dan tidak berbau, kondisi untuk sarana air bersih dengan jarak sumber pencemaran seperti septi tank lebih dari $10 \mathrm{~m}$, hal ini berarti variabel kondisi dan kebersihan air sudah memenuhi syarat.

Untuk variabel sarana kamar mandi/WC, didapatkan hasil observasi dimana terdapat 5 kamar mandi/WC, dengan kondisi kamar mandi yang terlihat kotor dan tidak teratur, hal ini berarti variabel sarana kamar mandi tidak memenuhi syarat.

Untuk variabel sarana pembuangan sampah, didapatkan hasil observasi dimana terlihat tempat pembuangan sampah tidak dilengkapi dengan tutup dan jarak peletakan tempat pembuangan sementara dengan ruang kelas, asrama $<$ dari $10 \mathrm{~m}$, hal ini berarti tidak memenuhi syarat.

Untuk variabel kondisi kamar, didapatkan hasil observasi dimana terdapat 8 kamar tidur santriwati, dengan kondisi yang sangat kotor dan tidak teratur, hal ini berarti variabel kondisi kamar tidak memenuhi syarat kesehatan.

Untuk variabel kepadatan hunian kamar, didapatkan hasil observasi dimana terdapat 8 kamar tidur, dengan masing-masing kamar berukuran 7 meter $\mathrm{x} 7$ meter dan setiap kamar terdiri dari 12 tempat tidur tingkat 2 dan dihuni 20-23 orang. Hal ini tidak sesuai dengan standar kesehatan.

\section{Analisa Univariat}

Tabel 2. Distribusi Frekuensi Responden Berdasarkan Univarat Responden Pondok pesantren Anshor Al-Sunah Kabupaten Kampar

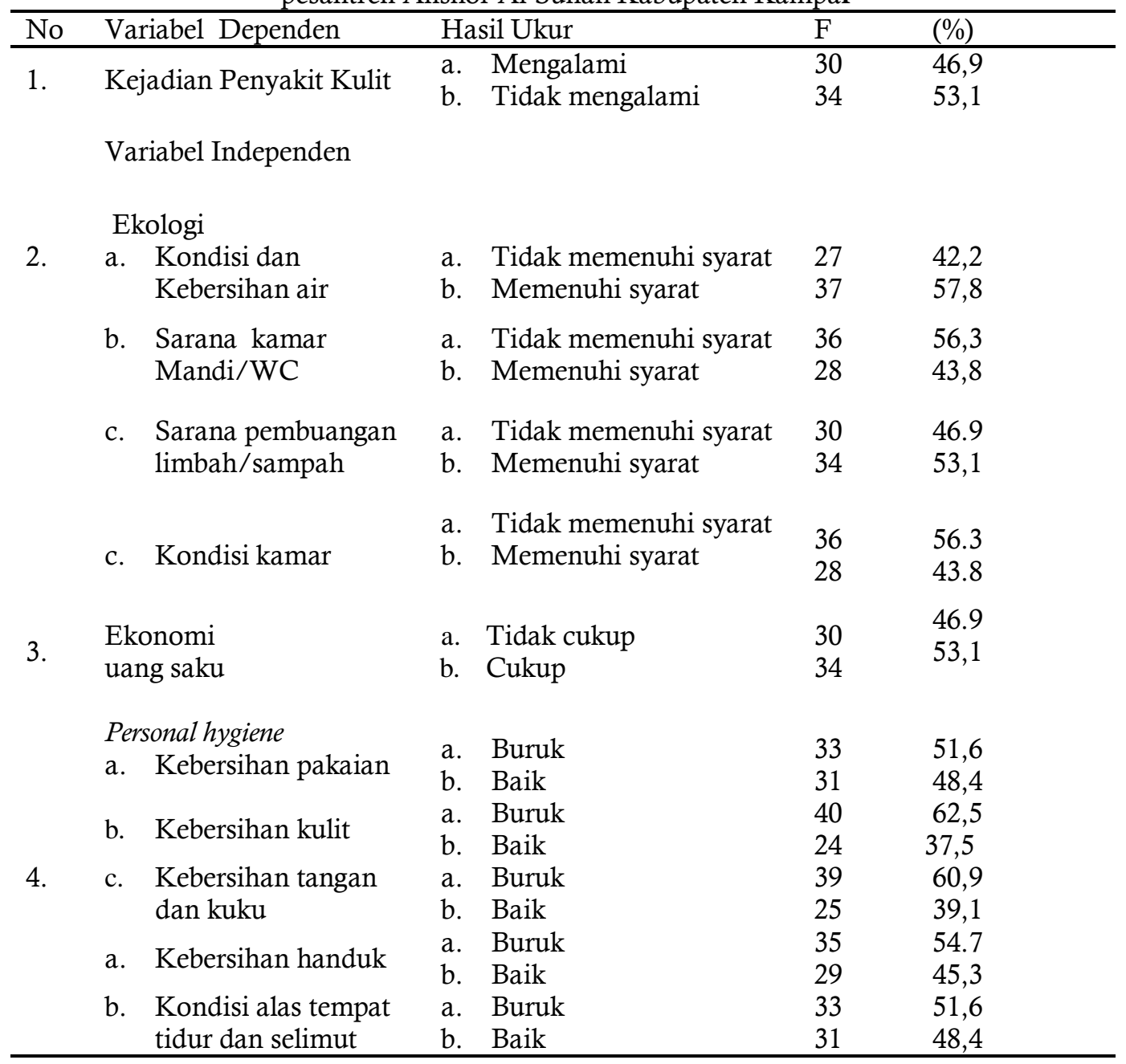

Berdasarkan Tabel 2 diketahui, dari 64 responden yang di teliti, untuk variabel ekologi yang terdiri dari kondisi dan kebersihan air didapatkan bahwa sebanyak 27 santriwati $(42,9 \%)$ tidak memenuhi syarat, 


\section{SEHATI}

Jurnal Kesehatan
Vol 1, No 2, Agustus 2021, p. 73-82 e-ISSN : 2775-6963 | p-ISSN : 2775-695 DOI: https://doi.org/10.52364/sehati.v1i2.8

santriwati menyatakan bahwa kondisi air dan kebersihan air tidak selalu dalam kondisi bersih dan kekurangan air pada saat mandi ataupun mencuci pakaian. Sarana kamar mandi/WC didapatkan sebanyak 36 santriwati $(56,3 \%)$ tidak memenuhi syarat, santriwati menyatakan bahwa kamar mandi masih terdapat genangan air yang menyebabkan tersumbat. Sarana pembuangan limbah/sampah didapatkan sebanyak 30 santriwati $(46,9 \%)$ tidak memenuhi syarat, santriwati menyatakan bahwa sampah tidak dibuang setiap hari atau dikosongkan 1x24 jam. Kondisi kamar didapatkan sebanyak 36 santriwati $(56,3 \%)$ tidak memenuhi syarat, santriwati menyatakan bahwa kamar tidak selalu dalam kondisi bersih dan rapi.

Untuk variabel ekonomi uang saku didapatkan sebanyak 30 santriwati $(46,9 \%)$ uang saku tidak cukup, santriwati menyatakan bahwa uang saku tidak cukup untuk memenuhi kebutuhan mandi atau membeli peralatan mandi.

Untuk variabel personal hygiene yang terdiri dari kebersihan pakaian didapatkan sebanyak 33 santriwati $(51,6 \%)$ kebersihan pakaian buruk dan santriwati menyatakan bahwa mereka pernah bertukar pakaian dengan santri lainnya dan saat merendam pakaian disatukan dengan santri lain, tidak menjemur pakaian dibawah terik matahari. Kebersihan kulit didapatkan sebanyak 40 santriwati $(62,5 \%)$ kebersihan kulit buruk dan santriwati menyatakan bertukar peralatan mandi dengan santri lainnya dan sabun tidak disimpan setelah mandi. Kebersihan tangan dan kuku didapatkan sebanyak 39 santriwati $(60,9 \%)$ kebersihan tangan dan kuku buruk, santriwati menyatakan tidak memotong kuku sekali seminggu, mencuci tangan menggunakan sabun setelah $\mathrm{BAB} / \mathrm{BAK}$, dan tidak menyikat kuku pada saat mandi menggunakan sabun. Kebersihan handuk didapatkan sebanyak 35 santriwati $(54,7 \%)$ kebersihan handuk buruk, santriwati menyatakan masih bertukar handuk dengan santri lain, tidak menjemur handuk setelah mandi, dan mencuci handuk disatukan dengan santri lain dan menggunakan handuk tidak selalu dalam keadaan kering. Kebersihan tikar dan selimut didapatkan sebanyak 33 santriwati $(51,6 \%)$ kebersihan tikar dan selimut buruk, santriwati menyatakan masih bertukar selimut dengan santri lain, tidak mencuci alas tempat tidur seminggu sekali, dan tidur bersama-sama dengan santri lainnya.

Penyakit kulit sering dijumpai pada masyarakat terutama yang padat penghuninya seperti asrama dapat mempengaruhi proses penularan atau perpindahan penyakit dari satu orang ke orang lain. Faktor resiko penyakit kulit diantaranya perilaku hidup bersih dan sehat, kondisi sanitasi lingkungan, sarana air bersih, personal hygiene seperti kebersihan badan, kuku, kulit, pakaian dan kondisi tempat tidur yang diperlu diperhatikan. Penelitian ini sejalan dengan penelitian Yasin (2009) disebutkan bahwa terdapat perbedaan kejadian penyakit kulit yang bermakna antara seorang yang hidup dengan sanitasi lingkungan yang baik dengan seseorang yang hidup dengan sanitasi lingkungan yang buruk.

Personal hygiene seseorang menentukan status kesehatan dalam menjaga kesehatan dan mencegah terjadinya penyakit terutama gangguan pada kulit.

Penelitian ini sejalan dengan Irijal (2004) menyatakan kebersihan diri dikaitkan dengan yang pernah menderita penyakit kulit $51 \%$ karena kurangnya menjaga kebersihan diri terutama pakaian.

\section{Analisa Bivariat}

Berdasakan analisa univariat dapat dilihat pada tabel berikut :

Tabel 3. Kolerasi dengan Uji Chi Square

\begin{tabular}{|c|c|c|c|}
\hline No & Variabel penelitian & Sig & Keterangan \\
\hline \multirow[t]{5}{*}{1.} & Ekologi (X1) & & \\
\hline & a. Kondisi dan Kebersihan air & .739 & Tidak Siginifkan \\
\hline & b. Sarana kamar Mandi/WC & .000 & Signifikan \\
\hline & $\begin{array}{l}\text { c. Sarana pembuangan } \\
\text { limbah/sampah }\end{array}$ & .000 & Signifikan \\
\hline & d. Kondisi kamar & 002 & Signifikan \\
\hline \multirow[t]{2}{*}{2.} & Ekonomi (X2) & & \\
\hline & Uang saku & .594 & Tidak Siginifkan \\
\hline \multirow[t]{6}{*}{3.} & Personal hygiene (X3) & & \\
\hline & a. Kebersihan pakaian & .000 & Signifikan \\
\hline & b. Kebersihan kulit & .000 & Signifikan \\
\hline & c. Kebersihan tangan dan kuku & .000 & Signifikan \\
\hline & d. Kebersihan handuk & .010 & Signifikan \\
\hline & $\begin{array}{l}\text { e. Kondisi alas tempat tidur dan } \\
\text { selimut }\end{array}$ & .006 & Signifikan \\
\hline
\end{tabular}




\section{SEHATI}

Jurnal Kesehatan
Vol 1, No 2, Agustus 2021, p. 73-82 e-ISSN : 2775-6963 | p-ISSN : 2775-695 DOI: https://doi.org/10.52364/sehati.v1i2.8

Berdasarkan Tabel 4.2 diketahui, dari 10 variabel yang dianalisa secara bivariate didapatkan hasil variabel kondisi air dan uang saku santri tidak signifikan atau tidak ada pengaruh terhadap kejadian penyakit kulit karena nilai sig $>0,05$. Sedangkan untuk variabel lainnya nilai sig $<0,05$ yang berarti ada pengaruh terhadap kejadian penyakit kulit.

Salah satu faktor yang mempengaruhi kejadian penyakit kulit adalah ekologi yang merupakan suatu kondisi lingkungan mampu menopang keseimbangan ekologi antara manusia dan lingkungannya untuk tercapainya kualitas hidup manusia yang sehat. Jika ekologi buruk seperti akses air yang sulit, sarana kamar mandi, sarana pembuangan limbah/sampah tidak memenuhi syarat, kondisi ruangan yang kotor dan kepadatan hunian tidak sesuai dengan standar maka akan berpengaruh pada kesehatan dan beresiko terkena penyakit kulit. Dengan melakukan analisis hubungan, sering kali menunjukkan tingkat hubungan yang tinggi antara berbagai gejala dengan parameter lingkungan atau sanitasi dasar yang buruk (Achmadi, 2011).

Penelitian ini sejalan dengan penelitian yang dilakukan oleh Cindy et all (2018) ada hubungan sanitasi lingkungan dengan kejadian penyakit kulit didapat kan nilai $p$ sebesar 0,029 artinya ada pengaruh signifikan antara sanitasi lingkungan dengan kejadian penyakit kulit.

Personal hygiene seseorang menentukan status kesehatan dalam menjaga kesehatan dan mencegah terjadinya penyakit terutama gangguan pada kulit. Tetapi masih terdapat kebersihan perseorangan santriwati yang masih kurang dalam memperhatikan kebersihan perseorangan terkait variabel kebersihan pakaian, kebersihan kulit, kebersihan tangan dan kuku, kebersihan handuk, dan kebersihan tikar dan selimut. Sedangkan ekonomi tidak mempengaruhi kejadian penyakit kulit hal ini disebabkan banyak santriwati yang mendapatkan uang saku cukup, namun mereka tidak mau membeli peralatan mandi sehingga mereka cenderung menggunakan sabun teman lainnya, hal ini sangat beresiko terjadinya penularan penyakit kulit pada santriwati lainnya.

Dengan ini penelitian sejalan dengan penelitian Hilma (2013), dimana hasil penelitian didapatkan $29(54,7 \%)$ responden terdiagnosis penyakit kulit dan $24(45,3 \%)$ tidak terdiagnosis. Personal hygiene berhubungan terhadap kejadian penyakit kulit dengan p=0,008; RP 1,917 (CI 1,205-3,049).

\section{Analisa Mutivariat}

Analisa multivariat dalam penelitian menggunakan Regresi logistik biner yang merupakan suatu metode analisis data yang digunakan untuk mencari pengaruh antara variabel respon (y) yang bersifat biner atau dikotomus dengan variabel prediktor (x) yang bersifat politokomus. Berikut adalah hasil analisis regresi logistik biner untuk mengetahui Pengaruh Sanitasi Lingkungan Terhadap Kejadian Penyakit kulit Pada Santriwati di Pondok Pesantren Anshor Al-Sunah Kabupaten Kampar.

Hasil Uji Signifikansi Parameter secara Serentak

Uji signifikansi parameter secara serentak dilakukan untuk mengeahui apakah variabel prediktor memberikan pengaruh yang signifikan terhadap model. Berikut merupakan hasil uji signifikansi parameter secara serentak terhadap faktor-faktor yang diduga penyebab penyakit kulit. Berikut merupakan hasil uji signifikansi parameter secara.

a. $\mathrm{H}_{0}=\beta_{1}=\beta_{2}=\beta_{3}=\beta_{4}=\beta_{5}=\beta_{6}=\beta_{7}=0$ (variabel predictor tidak memberikan pengaruh yang siginifikan terhadap model)

b. $\quad \mathrm{H}_{1}=\beta_{i} \neq 0$ dimana $i=1,2,3,4,5,6,7$ minimal terdapat satu variabel prediktor yang berpengaruh signifikan terhadap model

Daerah kritis ditolak jika pvalue < alpa $(0,05)$

Tabel 4. Hasil Uji Signifikansi Parameter Secara Serentak

\begin{tabular}{llccc}
\hline & & Chi-square & $D f$ & Sig. \\
\hline Step 1 & Step & 23.739 & 3 & .000 \\
& Block & 23.739 & 3 & .000 \\
& Mode & 23.739 & 3 & .000 \\
& 1 & & & \\
\hline
\end{tabular}

Berdasarkan Tabel 4.3 diketahui pada uji Signifikansi Parameter Secara Serempak diketahui nilai signifikasi diperoleh $0,000<0,05$, yang berarti terdapat satu variabel yang berpengaruh signifikan.

\section{Uji Parsial}

Uji signifikansi parameter secara parsial dilakukan untuk mengetahui apakah variabel yang signifikan dari hasil uji secara serentak memberikan pengaruh yang signifikan terhadap model yang terbentuk. Berikut hasil uji pengujian signifikansi parameter secara parsial. 
Tabel 5. Hasil Uji Signifikansi Parameter Secara Parsial

\begin{tabular}{lcccc}
\hline \multicolumn{1}{c}{ Variabel penelitian } & $\mathrm{B}$ & Wal & Df & P-Value \\
& & $\mathrm{d}$ & & .006 \\
\hline Ekologi & 1.770 & 7.640 & 1 & .501 \\
Ekonomi & -.418 & .453 & 1 & .001 \\
Personal hygiene & 2.266 & 10.730 & 1 & .037 \\
Constant & -1.148 & 4.368 & 1 & \\
\hline
\end{tabular}

Berdasarkan Tabel 5 diketahui pada Uji Signifikansi Parameter Secara Parsial diketahui nilai signifikasi untuk ekologi dan personal hygiene < alpha $(0,05)$, sedangkan untuk variabel ekonomi nilai signifikasi $>$ alpha $(0,05)$. Dari hasil tersebut dapat disimpulkan bahwa variabel ekologi dan personal hygiene mempengaruhi penyakit kulit.

Berdasarkan hasil penelitian ekologi yang dilakukan di pondok pesantren Anshor Al-Sunah Kabupaten Kampar didapatkan hasil obeservasi dimana terdapat 5 kamar mandi/WC, dengan kondisi yang sangat kotor dan tidak teratur banyak peralatan mandi yang berserakan dilantai kamar mandi. Selain itu didapatkan hasil obeservasi dimana terlihat tempat pembuangan sampah tidak dilengkapi dengan tutup dan jarak peletakan tempat pembuangan sementara dengan ruang kelas, asrama $<$ dari $10 \mathrm{~m}$. Berdasarkan hasil penelitian didapatkan hasil obeservasi dimana terdapat 8 kamar tidur santriwati, dengan kondisi yang sangat kotor dan tidak teratur dan tidak memenuhi syarat kesehatan. Selain itu hasil obeservasi dimana terdapat 8 kamar tidur, dengan masing-masing kamar berukuran 7 meter x 7 meter dan setiap kamar terdiri dari 10 tempat tidur tingkat 2 dan dihuni 20-23 orang.

Penelitian ini sejalan dengan penelitian yang dilakukan Ma'rufi (2005) terdapat hubungan bermakna antara sanitasi lingkungan dan skabies di pondok pesantren kabupaten Lamongan hal ini juga dinyatakan di penelitian Al Audhah et al., (2012) menunjukkan adanya hubungan yang bermakna antara sanitasi dan kejadian skabies dilihat dari kepadatan pondok pesantren. Sanitasi lingkungan adalah status kesehatan untuk suatu lingkungan yaitu perumahan, pembuangan kotoran, sarana air bersih, kualitas udara dan sebagainya. Banyak sekali permasalahan lingkungan yang harus diperhatikan dan akan mengganggu suatu tercapainya kesehatan lingkungan.

Berdasarkan hasil penelitian diketahui ada pengaruh antara kebersihan kulit dengan penyakit kulit pada santriwati. Hal ini didukung oleh penelitian Yadi (2013), kebersihan kulit sangat berpengaruh terhadap kejadian penyakit kulit, karena penyakit kulit adalah penyakit zoonosis yang menyerang kulit, mudah menular dari manusia ke manusia, dari hewan ke manusia, atau sebaliknya, dapat mengenai semua ras dan golongan di seluruh dunia yang disebabkan oleh tungau. Hasil penelitian ini juga sejalan dengan hasil penelitian Frenki (2011) tentang hubungan personal hygiene santriwati dengan kejadian penyakit kulit dan tinjaun sanitasi lingkungan pesantren darel hikmah kota Pekanbaru tahun 2011. Hasil penelitian menunjukkan bahwa terdapat hubungan antara kebersihan kulit dengan kejadian penyakit kulit Penyakit kulit dengan nilai $p=0,025$.

Peranan kulit dalam menjaga keutuhan tubuh tidak selamanya mudah. Sebagai organ proteksi peranan kulit tidak luput dari berbagai masalah-masalah yang bisa membahayakan kulit itu sendiri. Untuk selalu memelihara kebersihan kulit harus selalu memperhatikan personal hyieneg seperti, menggunakan barang-barang keperluan sehari-hari milik sendiri, mandi minimal $2 \mathrm{x}$ sehari, mandi memakai sabun, menjaga kebersihan pakaian, kebersihan handuk, kulit, tangan dan kuku (Potter dan Perry. 2006).

Berdasarkan hasil penelitian dan teori diatas, peneliti berpendapat bahwa ada hubungan antara terhadap kebersihan kulit dengan kejadian penyakit kulit, disebabkan karena seperti yang kita ketahui kulit merupakan lapisan terluar dari organ tubuh. Kulit sangat sensitif terhadap bakteri dan jamur yang ditularkan melalui aktifitas dari luar rumah maupun di dalam rumah. Terutama penyakit penyakit kulit sangat berpengaruh terhadap kebersihan kulit dimana yang kita ketahui di Pondok Pesantren tersebut personal hygiene masih tergolong buruk. Santriwati mengatakan pada saat mandi menggunakan sabun secara bersama-sama, penggunaan air yang terbatas dikarenakan jumlah santriwati yang begitu banyak menyebabkan pemakaian air terbatas, sehingga para santriwati akan mudah terjangkit penyakit kulit dan didukung oleh lingkungan disekitar asrama tersebut. Sedangkan sebagian responden yang memiliki kebersihan kulit yang bersih namun mengalami penyakit kulit, hal ini disebabkan karena faktor lain yaitu responden tersebut tertular dari temannya yang menderita penyakit kulit.

Masih ada kebersihan tangan dan kuku santriwati yang belum bersih diantaranya kebiasaan memotong kuku seminggu sekali serta mencuci tangan sesudah BAB/BAK dengan menggunakan sabun dikarenakan santriwati beranggapan dengan mencuci tangan dengan air sudah bersih. Padahal yang kita ketahui sebelum makan dan pada saat setelah $B A B$ cucilah tangan dengan sabun karena sabun akan membunuh kuman tersebut. Serta pengetahuan dan kebiasaan santriwati tidak menjaga PHBS masih 


\section{SEHATI}

Jurnal Kesehatan
Vol 1, No 2, Agustus 2021, p. 73-82 e-ISSN : 2775-6963 | p-ISSN : 2775-695 DOI: https://doi.org/10.52364/sehati.v1i2.8

rendah di lihat dari pernyataan-pernyataan yang di kemukakan pada saat penelitian. Seseorang dengan kebersihan tangan dan kuku yang tidak bersih sangat berpeluang untuk terjangkitnya penyakit kulit kebersihan tangan dan kuku merupakan faktor penting dalam menjaga penularan penyakit kulit. Sedangkan sebagian responden yang memiliki kebersihan tangan dan kuku yang bersih namun mengalami penyakit kulit, hal ini disebabkan karena faktor lain yaitu responden tersebut tertular dari temannya yang menderita penyakit kulit. Kebersihan handuk yang belum bersih sebagian santriwati masih belum menjemur handuknya setelah mandi, tetapi membiarkan handuk tersebut bergantungan di dalam asrama dalam kondisi lembab. Dengan kebiasaan tersebut memberikan kesempatan bakteri jamur atau tungau bertahan hidup pada handuk penderita dalam keadaan lembab. Untuk itu sebaiknya santriwati pergantian handuk dilakukan 2 kali seminggu agar tidak terkena penyakit kulit scabies dan sebaiknya setelah mandi di jemur agar kuman tersebut mati pada suhu yang panas yaitu sinar matahari. Selain itu juga masih ada sebagian santriwati yang dalam satu kamar masih menggunakan handuk bersama-sama dengan teman sekamar, sehingga penyakit kulit dapat dengan mudah menular dari satu orang ke orang yang lain. Sedangkan sebagian responden yang memiliki kebersihan handuk yang bersih namun mengalami penyakit kulit, hal ini disebabkan karena faktor lain yaitu responden tersebut tertular dari temannya yang menderita penyakit kulit. Maka dari itu diharapkan bagi santriwati diharapkan agar santriwati selalu menjaga personal hygiene seperti selalu menjaga kebersihan handuk dan tidak bergantian handuk dengan yang lain, sehingga terhindar dari penyakit kulit santriwati.

Berdasarkan hasil penelitian diketahui ada pengaruh antara kebersihan handuk dengan penyakit kulit pada santriwati. Hal ini didukung oleh penelitian Rohmawati (2010) menunjukkan bahwa bergantian handuk mempunyai risiko terkena penyakit penyakit kulit sebesar 2,719 kali bila dibandingkan dengan yang tidak bergantian handuk. Memiliki kebiasaan menjemur handuk di dalam kamar, dan tidak semua santriwati memiliki alat mandi sendiri-sendiri, jadi saat santriwati mandi menggunakan alat mandi bergantian dengan teman santriwati, saling bergantian handuk karena santriwati tidak mengetahui bahwa kutu sarcoptes scabiei dapat bertahan hidup pada handuk dan dapat menularkan penyakit penyakit kulit.

Kebersihan handuk secara langsung mempengaruhi kesehatan, handuk yang kotor akan menjadi sarang beragam bakteri sehingga bukan tidak mungkin akan menggundang masalah kesehatan kulit, karena setiap hari paling tidak handuk digunakan 2 kali sehari. Ada baiknya handuk di beri perhatian lebih pada perawatan dan kebersihannya. Pastikan handuk kembali pada keadaan kering setelah menggunakannya agar tidak tumbuh jamur dan ada baiknya untuk merendam handuk secara terpisah dengan pakaian lainnya (Potter dan Perry, 2006).

Untuk menjaga kebersihan tempat tidur kita harus selalu mengganti sprei dan sarung setidaknya satu kali seminggu. Karena jika lebih dari satu minggu pasti akan banyak debu yang menempel pada sprei dan sarung. Tidak hanya itu, di dalam debu terdapat tungau yang bisa menembus pori-pori sprei dan sarung bantal dan ini salah satu pencetus alergi yang bisa membuat orang menjadi sesak napas, bersinbersin, gatal-gatal ataupun mengakibatkan penyakit kulit. Tetapi masih terdapat santriwati alas tempat tidur dan selimut saat mencuci dijadikan satu dengan santri lainnya, dan saling bertukar tempat tidur dengan santri lainnya atau tidur bersama dengan santri lainnya. Tidur bersama dan bersetuhan bagian kulit seseorang dengan penderita penyakit kulit memberikan kesempatan untuk kontak langsung maupun tidak langsung dengan penderita penyakit kulit. Sedangkan penularan secara tidak langsung pada saat tidur bersama dan berhimpitan dapat terjadi melalui alas tidur yang digunakan dan penggunaan selimut secara bersama-sama (Potter dan Perry, 2006).

Penelitian ini sejalan dengan penelitian yang dilakukan oleh Rohmawati (2010) dalam penelitiannya yaitu ada hubungan antara tidur bersetuhan dengan kejadian penyakit kulit di Pondok Pesantren Muayyad Surakarta. Penularan melalui kontak tidak langsung seperti melalui perlengkapan tidur memegang peranan penting (Mansyur, 2007). Berdasarkan penelitian Handayani (2007), menunjukkan 44 orang $(127,9 \%)$ terkena penyakit kulit dan ada hubungan antara kebiasaan tidur bersama, kebiasaan pemakaian selimut tidur dan kebiasaan tidur bersama.

\section{Hasil Uji Kesesuaian Model}

Uji kesesuaian model dilakukan untuk mengetahui apakah model yang dibentuk sudah sesuai atau belum. Berikut hasil dari uji kesesuaian model. Hipotesis :

$\mathrm{H}_{0}$ : Model sesuai (tidak terdapat perbedaan yang signifikan antara hasil pengamatan dengan kemungkinan hasil prediksi model)

$\mathrm{H}_{1}$ : Model tidak sesuai (terdapat perbedaan yang signifikan antara hasil pengamatan dengan kemungkinan hasil prediksi model)

Taraf signifikan : alpha $=0,05$ 


\section{SEHATI}

Jurnal Kesehatan
Vol 1, No 2, Agustus 2021, p. 73-82 e-ISSN : 2775-6963 | p-ISSN : 2775-695 DOI: https://doi.org/10.52364/sehati.v1i2.8

Berdasarkan hasil uji kesesuaian model diketahui nilai $X_{\text {hitung }}(1.426)$ kurang dari $X_{\text {hitung }}(15,507)$. Sedangkan nilai pvalue $(0,964>0,05$, sehingga dapat diputuskan bahwa model sesuai artinya tidak terdapat perbedaan yang signifikan antara hasil pengamatan dengan kemungkinan hasil prediksi model. Kebaikan model yang didapatkan dalam analisis digunakan untuk mengetahui sejauh mana variabel prediktor dapat menjelaskan model yang terbentuk dengan melihat nilai $R$ - $s q$ yaitu sebesar 0,964 , hal ini menunjukkan bahwa nilai Nagelkerke $R$ - $S q$ sebesar $61,4 \%$ yang berarti model dapat dijelaskan oleh variabel prediktor sebesar $61,4 \%$.

\section{Hasil Odds ratio (OR)}

Odds ratio merupakan nilai kecenderungan antara satu kategori dengan kategori lain pada variabel penjelas yang kualitatif. Nilai rasio kecenderungan dapat dilihat pada tabel berikut.

Tabel 6. Nilai Odds Ratio

\begin{tabular}{ll}
\hline Estimasi Parameter & Odds Ratio \\
\hline Ekologi (X1) & 5,871 \\
Ekonomi (X2) & 0,658 \\
Personal hygiene (X3) & 9,637 \\
\hline
\end{tabular}

Tabel 6 menunjukkan bahwa nilai Odds ratio dari ekologi dan personal hygiene lebih dari 1 artinya ekologi dan personal hygiene cenderung mempunyai resiko paling tinggi terhadap penyakit kulit. Nilai odd ratio (OR) ekologi sebesar 5,871 maka diketahui bahwa responden yang memiliki ekologi yang buruk berpeluang 5,871 kali beresiko lebih tinggi menderita penyakit kulit jika dibandingkan dengan responden yang memiliki ekologi yang baik. Nilai odd ratio (OR) ekonomi sebesar 0,658 maka diketahui bahwa responden yang ekonominya tidak mencukupi berpeluang 0,658 kali beresiko lebih tinggi dibandingkan dengan responden yang ekonominya cukup. Nilai odd ratio (OR) personal hygiene sebesar 9,637 maka diketahui bahwa responden yang memiliki personal hygiene buruk berpeluang 9,637 kali beresiko lebih tinggi menderita penyakit kulit jika dibandingkan dengan responden yang memiliki personal hygiene yang baik.

Sanitasi lingkungan adalah suatu kondisi atau keadaan lingkungan yang optimum sehingga berpengaruh positif terhadap terwujudnya suatu kesehatan yang optimum pula. Sanitasi lingkungan adalah prinsip-prinsip untuk meniadakan atau mengurangi Faktor-Faktor pada lingkungan yang dapat menimbulkan penyakit, melalui kegiatan-kegiatan yang ditunjukkan untuk mengendalikan : sanitasi air, pembuangan kotoran, limbah dan sampah, sanitasi udara, vektor dan binatang pengerat (Soedjadi, 2013).

Penelitian ini sejalan dengan Cindy et all (2018) diperoleh nilai 1,4 sehingga disimpulkan bahwa sanitasi lingkungan yang buruk mempunyai resiko 1,4 kali untuk menderita penyakit kulit dibandingkan santriwati yang sanitasi lingkungannya yang baik.

Berdasarkan penelitian Yasin (2009) didapatkan nila OR sebesar 1,940 menunjukkan bahwa personal hygiene yang buruk merupakan faktor resiko kejadian penyakit kulit.

Dari hasil dan penelitian diatas sanitasi lingkungan dan personal hygiene sangat berpengaruh terhadap penyakit kulit, karena kulit sangat sensitif terhadap bakteri dan jamur yang ditularkan melalui aktifitas dari luar maupun didalam asrama. Pondok pesantren tersebut masih kurangnya memperhatikan kebersihan perseorangan dan sarana prasarana lingkungan pondok masih belum optimal.

\section{Hasil Uji Ketepatan Klasifikasi Model}

Persentase ketepatan klasifikasi adalah rasio antara jumlah observasi-observasi yang diklasifikasikan secara tepat oleh model dengan jumlah seluruh observasi.

Tabel 7. Ketepatan Klasifikasi Model

\begin{tabular}{llll}
\hline Y & \multicolumn{2}{c}{ Prediksi } & Total \\
\cline { 2 - 3 } & Ya & Tidak & \\
Ya & & & 66.7 \\
Tidak & 20 & 10 & 85.3 \\
Total & 5 & 29 & 76.6 \\
\hline
\end{tabular}

Tabel 7 menunjukkan bahwa ekologi dan personal hygiene diklasifikasikan sebanyak 30 santriwati 66.7\% yang mengalami penyakit kulit di Pondok Pesantren Anshor Al-Sunah Kabupaten Kampar 


\section{SEHATI}

Jurnal Kesehatan
Vol 1, No 2, Agustus 2021, p. 73-82 e-ISSN : 2775-6963 | p-ISSN : 2775-695 DOI: https://doi.org/10.52364/sehati.v1i2.8

sedangkan sebesar 34 santriwati $85.3 \%$ tidak mengalami penyakit kulit. Model dapat mengklasifikasikan secara tepat $76,6 \%$.

Hal ini diperkuat dengan penelitian Ma'rufi (2005) bahwa prevalensi penyakit kulit pada pondok pesantren di Kabupaten Lamongan dengan total yang mengalami $64,2 \%$. Menurut penelitian Handayani (2007) juga menyebutkan di Pondok Pesantren Nihayatul Amal Waled Cirebon menunjukkan bahwa santri laki-laki berpotensi terjangkit skabies sebanyak $62,9 \%$.

Namun hal ini tidak sejalan dengan penelitian Handayani (2007), menunjukkan hanya 44 orang $(127,9 \%)$ terkena penyakit kulit dan ada hubungan antara kebiasaan tidur bersama, kebiasaan pemakaian selimut tidur dan kebiasaan tidur bersama, hal ini menggambarkan responden yang mengalami penyakit kulit lebih banyak dibandingkan dengan hasil penelitian ini, jumlah responden yang terkena penyakit kulit sebanyak $76,6 \%$. Adanya perbedaan ini disebabkan oleh faktor kondisi tempat penelitian yang bebeda sehingga frekuensi kejadiannya penyakit kulit tidak sama.

Menurut teori Aludin (2018), penyakit kulit merupakan kelainan kulit akibat adanya jamur, bakteri, parasit virus maupun infeksi yang dapat menyerang siapa saja disegala umur. Penyakit kulit dapat menyerang seseorang apabila orang itu memiliki tingkat kekebalan tubuh yang kurang baik. Lingkungan yang sehat dan bersih juga akan membawa efek yang baik bagi kulit. Demikian pula sebaliknya, lingkungan yang kotor akan menjadi sumber munculnya berbagai macam penyakit antara lain penyakit kulit

Menurut asumsi peneliti berdasarkan hasil observasi terkait masalah penyakit kulit, diketahui sebagian besar santriwati yaitu $76.6 \%$ mengalami penyakit kulit dan $45 \%$ diantaranya adalah mengalami penyakit kulit jenis skabies. Salah satu penyebab penyakit scabies adalah kurangnya personal hygiene yang dimiliki santriwati, dalam hal ini personal hygiene menjadi penting karena personal hygiene yang baik akan meminimalkan terpaparnya mikroorganisme yang ada dimana-mana dan pada akhirnya mencegah seseorang terkena penyakit. Menurut hasil penelitian yang dilakukan didapatkan bahwa kebersihan kulit yang baik pada bukan penderita penyakit kulit dibandingkan dengan kebersihan kulit yang baik pada penderita penyakit kulit, sedangkan kebersihan kulit yang buruk pada bukan penderita penyakit kulit dan kebersihan kulit yang buruk pada penderita penyakit kulit. Seseorang dikatakan memiliki kebersihan diri baik apabila, orang tersebut dapat menjaga kebersihan tubuhnya yang meliputi kebersihan kulit dilihat berdasarkan Praktik mandi disini mencakup frekuensi mandi, pemakaian sabun dan apakah sabun tersebut digunakan sendiri atau digunakan bergantian dengan penghuni kamar yang lain.

\section{KESIMPULAN}

Kondisi faktor ekologi mempengaruhi kejadian penyakit kulit pada santriwati, hal ini disebabkan karena kondisi ekologi di Pondok Pesantren Anshor Al-Sunah Kabupaten Kampar belum optimal. Kondisi faktor ekonomi tidak mempengaruhi kejadian penyakit kulit pada santriwati, hal ini disebabkan karena kecukupan uang saku santriwati sudah cukup dalam memenuhi kebutuhan membeli peralatan mandi. Kondisi faktor personal hygiene mempengaruhi kejadian penyakit kulit pada santriwati, hal ini disebabkan karena perilaku personal hygiene santriwati yang masih kurang di Pondok Pesantren Anshor AlSunah Kabupaten Kampar.

\section{UCAPAN TERIMAKASIH}

Ucapan terima kasih penulis sampaikan kepada pihak Pondok Pesantren Anshor Al-Sunah Kabupaten Kampar yang telah memberikan data dan informasi sehingga terlaksananya penelitian ini di lapangan.

\section{DAFTAR PUSTAKA}

Achmadi UF. 2011. Dasar-dasar Penyakit Berbasis Lingkungan. Jakarta : Rajawali pers

Al Audhah N. Umniyati. S.R. Siswati. A.S. 2012. Faktor Resiko Penyakit kulit Pada Siswa Pondok Pesantren. Jurnal Buski Vol 4, No. 1

Aludin. 2018. Ilmu Kesehatan Masyarakat dalam Konteks Kesehatan Lingkungan. Jakarta : ECG

Cindy T.M. Prasetyo S. Aryoko W. 2018. Pengaruh Sanitasi Lingkungan terhadap Prevalensi terjadinya Penyakit Skabies di Pondok Pesantern Matholilul Huda Al Kautsar Kabupaten Pati. Jurnal Kedokteran Vol 7, No. 1 


\section{SEHATI}

Jurnal Kesehatan
Vol 1, No 2, Agustus 2021, p. 73-82

e-ISSN : 2775-6963 | p-ISSN : 2775-695 DOI:

https://doi.org/10.52364/sehati.v1i2.8

Dara. 2018. Ilmu Kesehatan Masyarakat dalam Konteks Kesehatan Lingkungan. Jakarta : ECG

Djuanda. 2007. Panduan Praktis Mornologi dan Terminologi Penyakit Kulit. Jakarta : EGC

Frenki. 2011. Hubungan Personal Hygiene Santri dengan Kejadian Penyakit Kulit Infeksi Skabies dan Tinjauan Sanitasi Lingkungan Pesantren Darel Hikmah Kota Pekanbaru. Universitas Sumatra Utara

Harahap. 2010. Ilmu Penyakit Kulit. Jakarta: Sagung Seto

Handayani. 2007. Hubungan Antara Praktik Kebersihan Diri dengan Kejadian Skabies di Pondok Pesantren Nihayatul Amal Waled Kabupaten Cirebon. http://fkm.undip.ac.id/data/index.php?action=4\&idx=3264 [Diakses: 17 maret]

Hilma UD. 2013. Faktor-faktor yang mempengaruhi kejadian skabies di Pondok Pesantren Sleman Yogyakarta. JJKI, 6 (3), 148-157

Irijal. 2004. Perilaku Hidup Bersih dan Sehat. Jakarta: TIM

Indriana. 2012. Faktor yang berhubungan dengan kejadian penyakit kulit pada santriwati Dipondok pesantren Mualamin. Universitas Stikes Hangtuah

Mansyur, M. 2007, Februari. Pendekatan Kedokteran Keluarga pada Penatalaksanaan Skabies Anak Usia Pra-Sekolah. Majalah Kedokteran Indonesia. Vol. 57, No. 2. Hal: 63-67

Ma'rufi. 2005. Faktor Sanitasi Lingkungan yang Berperan terhadap Prevalensi Penyakit Scabies. Jurnal Kesehatan Lingkungan. Vol 2 No 1, Surabaya

Profil Kesehatan Provinsi Riau. 2017. Strategi Pengendalian Penyakit kulit di Pondok Pesantren. Diperoleh https://digilib.uns.ac.id/dokumen/abstrak/50958/ [diakses 10 september]

Potter. K dan Perry. A. 2006. Fundamental Keperawatan.. Jakarta: Salemba Medika. Hal 169-174

Rohmawati. 2010. Hubungan antara faktor pengetahuan dan perilaku dengan kejadian skabies di Pondok pesantren Al-Muayyad Surakarta. Diperoleh www.e-jurnal.com/2013/11/hubungan-antara-faktor-pengetahuandan-perilaku.html. [Diakses pada tanggal 18 november 2015]

Sa'adatin, Jumani, Riana, dan Tiana. 2015. Faktor-Faktor Yang Berhubungan Dengan Kejadian Penyakit kulit Di Pesantren Raudah Boyolali. Jurnal USU. respt.Vol 01 Nomor 02. Sumatra Utara

Surtina. 2013. Kesehatan Lingkungan dan PHBS. Jakarta : Nuha Medika

Soedjadi. 2013. Strategi Pengendalian Penyakit kulit di Pondok Pesantren. Diperoleh https://digilib.uns.ac.id/dokumen/abstrak/50958/

Yadi, K. 2013. Analisis Keluhan Gangguan Kulit Pada Masyarakat Pengguna Air Sungai Siak Dipelabuhan Sungai Duku Kota Pekanbaru. Jurnal USU.,respt.Vol 01 Nomor 02., Sumatra Utara.

Yasin. 2009. Hubungan Hygiene Pengguna Air Sungai Deli dengan Keluhan Kesehatan Kulit dan Tindakan Pencemaran Sungai di Kelurahan Hamdan Kota Medan. Jurnal UNRI.,ISBN.Vol 02 Nomor 03., Riau 